\title{
目視評価法を活用したコンクリート構造物の 品質確保の取組み
}

\author{
細田 暁*1 $\cdot$ 坂田 昇*2 ·渡邊賢三*3 $\cdot$ 佐藤和徳 $* 4$
}

\begin{abstract}
概 要 コンクリート構造物の耐久性に大きな影響を及ぼす表層部の品質は施工要因の影響を大きく受ける。本稿では, 表層部の品質を目視で評価し, PDCA により品質の向上につなげるための目視評価法について紹介する。なお, 橋脚や橋 台などの一般構造物用と, トンネル覆工コンクリート用に開発された目視評価法を説明する。目視評価法が活用された品 質確保の試行工事において明らかとなった目視評価法の特徵について述べ, 実際の試行工事で見られた施工者の工夫やそ の効果を紹介する。

キーワード : 表層品質, 目視評価法, PDCA, 品質向上, 品質確保
\end{abstract}

1.はじめに

コンクリート構造物には，安全性，使用性，耐久性， 復旧性，等の多くの性能が求められる。特に土木構造物 に扔いて重要となる耐久性とは,「各種性能が耐用期間 中に押いて環境作用によって構造物中の各種材料劣化に より不具合が生じない性能のこと」1)，や「劣化に対する 抵抗性 $\rfloor^{2)}$ などと定義されている。十分な耐久性を発揮 するためには，環境作用に対する十分な抵抗性をコンク リート構造物が持つ必要がある。

廣井勇先生は小樽築港工事に扔いて火山灰を活用した コンクリートブロックを用いたが，「ブロックに用いる コンクリートは，その強度よりは密度に重点を扔いて， 海水にたいして不透性であるようにすべきである」こと を強調されている3)。我が国の国土では，コンクリート 構造物は様々な環境で供用される。作用も, 設計段階等 に执いて人間が想定するものであるため, 十分に確実な ものとは言い切れないことや，コンクリート構造物の劣 化のメカニズムも完全に解明されているわけではないこ とを考えると、コンクリート構造物の耐久性を確保する ことは容易なことではない。

廣井勇先生の弟子であった吉田徳次郎先生は, 鉄筋コ ンクリートの欠点の一つとして,「施工が粗雑になり易 いこと」を挙げており, さらに、「鉄筋コンクリートを して十分にその特長を発揮させるためには，適当な設計 と同時に正直で親切な施工が極めて大切である。とし，

*1 ほそだ・あきら/横浜国立大学大学院 都市イノベーション研究 院 准教授 (正会員)

*2さかた・のぼる/鹿島建設㐺) 土木管理本部 土木技術部長（正 会員)

*3 わたなベ・けんぞう/鹿島建設(株) 技術研究所 土木材料グルー プ 上席研究員 (正会員)

*4 さとう・かずのり/国土交通省 東北地方整備局 地方事業評価 管理官
「鉄筋コンクリート構造物の強さは主としてコンクリー トの強さによるばかりでなく, 耐久性，外観，等もコン クリートによるものである。とコンクリートの施工の 重要性を指摘している゙)。

筆者らは，本稿の主題である，目視評価法を活用した 品質確保の取組みを推進してきだ) ○7)。コンクリート構 造物の施工時に, 補修を必要とする不具合が発生した場 合，これらの不具合が適切に補修されたとしても，当初 から適切に施工された構造物の性能には及ばず，劣化の 起点となる恐机がある，という認識のもと，「均質で密 実かつ一体性のある」コンクリート構造物を打込みで達 成する仕組みを構築してきた。東北地方整備局では, 復 興道路・復興支援道路等での品質確保の試行工事の結果 に基づき, 目視評価法と, 山口県で開発された施工状況 把握チェックシートを東北用にアレンジしたものを組み 合わせて,「均質で密実かつ一体性のある」コンクリー 卜を打込みにおいて目指す仕組みを構築した。「コンク リート構造物の品質確保の手引き（案）（橋脚, 橋台, 函渠, 擁壁編)」が 2015 年 12 月に,「コンクリート構造 物の品質確保の手引き（案）（トンネル覆エコンクリー 卜編)」が 2016 年 5 月に, 東北地方整備局から通知され, 局内の品質確保の試行工事で活用されている。なお，こ れらの手引きは,「均質で密実かつ一体性のある」コン クリートを打ち込む努力をした後, 適切に養生を行うこ とで耐久性を発揮するために必要な「緻密性」を得る努 力をする構成となっており, 緻密性の評価に表層透気試 験や表面吸水試験を活用する方法が記載されている。

コンクリート構造物の耐久性を確保する手法には様々 な方向性があると思われる。締固め不要の自己充填コン クリートの活用や，プレキャスト製品の活用，等も有効 であろう。しかし, 今一度, 適切な準備を促し, 施工の 基本事項の遵守による品質確保を日本の各地域で実践す 
るシステムの構築には意義があると考えている。山口県 や東北地方整備局での品質確保の取組みは, 各プレー ヤーが適切な役割を果たす「協働」を重要視している。 そして，より難易度の高い，凍結抑制剂を大量散布する ような過酷な環境で供用される $\mathrm{RC}$ 床版や $\mathrm{PC}$ 上部工の 耐久性確保のチャレンジは,「協働」の雲囲気が下地に あってこそ，実践できるものであることを，筆者らも現 実の試行工事で学んでいる。

本稿では, 目視評価法の概要と, 品質確保における PDCA の効果を紹介する。橋脚・橋台・函渠等の一般 的な構造物に扔ける目視評価法と, トンネル覆工コンク リート用に開発した目視評価法について説明する。さら に，目視評価法を適切に活用することにより，工事現場 に協働的な䨌囲気を醸成できることと, 目視評価法で評 価をすることにより様々な技術開発が促進されることを 実践してきた試行工事の結果に基づいて紹介する。

\section{2. 目視評価法の概要と品質確保における役割}

\section{1 一般構造物に用いる目視評価法}

目視評価法 ${ }^{5)-7)}$ とは，打ち込まれたコンクリートの脱型 後に出来ばえを目視で評価するものである。出来ばえを評 価することにより, 使用材料や施工方法の妥当性を検証 し, 次回の打込みへの改善に結びつけることが目的であ る。従来発注者の竣工検査に合格していた範囲を対象とし て, コンクリートの表層に生じる不具合を分類し，それぞ れの不具合について 4 段階のグレーディング評価を行う。

図-1 は橋台・橋脚・函渠・擁壁等の一般的な構造物 を対象とした目視評価の評価基準であり，施工中に生じ る不具合を, (1)沈みひび割れ, (2)表面気泡, (3)打重ね線, (4)型枠継ぎ目のノロ漏れ，(5)砂すじの5 項目に分類して いる。これまでは脱型後の出来ばえについて, 全体を漠 然と評価していたと言えるが，5つの項目に分類し，そ れぞれについて評価することで，数值化が可能になった のである。これまでは数值で評価されなかった表面の出 来ばえを，4段階のグレーディングにより定量評価する ことで, 施工方法の妥当性の検証や，施工方法改善のた めの PDCA に活用することができる。なお，東北地方
整備局の試行工事では, 満点を 4 点, 最低点を 1 点とし て, 0.5 点刻みで数值を付けることを許容している。

寒冷地の冬季施工に打いては, 型梊の存置期間や脱型 後の養生が不十分であることなどにより，微細ひび割れ が発生しやすく，耐久性に悪影響を及ぼす可能性がある ため, 川邊・阿波らは上記の目視評価法の項目に「微細 ひび割れ」を追加して活用している8 。また，筆者らは， コンクリート構造物の耐久性には直接影響しないと思わ れるものの, 美観の観点から「表面の色つや」を加えて

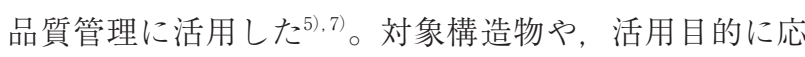
じて, 目視評価法の項目は追加・省略や変更が可能であ る。評価基準は, 実際の構造物で PDCA が適切に機能 するように現場での試行結果に基づいて設定するのがよ い。トンネル覆工コンクリート用に開発した目視評価法 は 2.2 で説明する。

\section{2 トンネル覆エコンクリートに用いる目視評価法}

供用中の NATM (New Austrian Tunneling Method) トンネルの二次覆工コンクリートには様々な劣化が生じ ている。二次覆工は部材厚が薄く, 施工しにくい部材で ある。既設構造物の点検結果の分析結果から, 施工に起 因すると思われるコールドジョイント, 施工目地部のう き・はく離・はく落, 施工目地から離れた箇所でのう き・はく離・はく落等が少なくない量ことも明らかと なっている。復興道路等においてトンネル覆工コンク リートの品質確保の試行工事を進めていくに際して, ト ンネル覆エコンクリート用の目視評価法を開発し, 現場 での PDCA に活用することとした。

図-2は, 復興道路の田老第六トンネルの工事で開発さ れたトンネル覆工コンクリート用の目視評価法である ${ }^{10)}$ 。 評価項目は, (1)はく離, (2)気泡, (3)水はしり・砂すじ, (4)色むら, 打重齐線, (5)施工目地不良, (6)検査空枠段差, の 6 つとしている。

東北地方整備局の試行工事に扔いては, 図-3に示す ように, 覆工コンクリートの左右のスプリングライン （SL）の下の側壁，左右のアーチ部，および天端部の計 5 箇所に対して, 6 項目の評価を行っている。

(1)はく離が生じるのは, セントルのケレン作業が不十

\section{Quality Attainment for Concrete Structures Using Visual Evaluation Method By A. Hosoda, N. Sakata, K. Watanabe and K. Sato \\ Concrete Journal, Vol.54, No.10, pp.1005 1014, Oct. 2016}

Synopsis The quality of the surface layer of concrete, which significantly affects the durability of concrete structures, is greatly influenced by construction factors. This paper introduces a visual evaluation method that leads to quality improvement through application of the PDCA cycle based on evaluation of the quality of the surface layer by naked eyes. The visual evaluation method herein described was developed for general structures such as piers and abutments, and for tunnel lining concrete. The characteristics of the visual evaluation method identified in the process of experimental construction applying this method for quality attainment are described, and various ideas implemented by contractors during the experimental construction and their results are introduced.

Keywords : surface quality, visual evaluation method, PDCA, quality improvement, quality attainment 


\begin{tabular}{|c|c|c|c|c|}
\hline \multirow{2}{*}{ 評価項目 } & \multicolumn{4}{|c|}{ 一般的に「良」とされる範囲 } \\
\hline & 4 点 & 3 点 & 2 点 & 1 点 \\
\hline $\begin{array}{c}\text { (1) } \\
\text { 沈みひび割れ }\end{array}$ & geresty & & $\because$ & \\
\hline & $\begin{array}{l}\text { ・ビーコン近傍にも沈みひび割 } \\
\text { れがない }\end{array}$ & 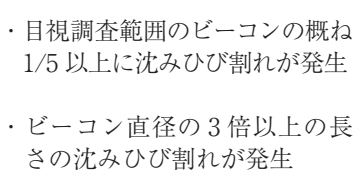 & $\begin{array}{l}\text { ·目視調査範囲のビーコンの概ね } \\
1 / 2 \text { 以上に沈みひび割れが生 } \\
\text { ·ビーコン直径の } 5 \text { 倍以上の長 } \\
\text { さの沈みひび割れが発生 }\end{array}$ & $\cdot 2$ 点の状態よりも劣る \\
\hline $\begin{array}{l}\text { (2) } \\
\text { 表面気泡 }\end{array}$ & . & & & \\
\hline & $\begin{array}{l}\cdot 5 \mathrm{~mm} \text { 以下の気泡がほととんどな } \\
\left.\text { い(目安: 概杖 } 50 \text { 個以下 } / \mathrm{m}^{2}\right)\end{array}$ & $\begin{array}{l}5 \mathrm{~mm} \text { 以下の気泡が認められる } \\
\left.\text { (日安: 概权 } 50 \text { 個以上 } \mathrm{m}^{2}\right)\end{array}$ & $\begin{array}{l}\cdot 10 \mathrm{~mm} \text { 以下の気泡が認められ } \\
\left.\text { る (目安: 概权 } 50 \text { 個以上 } / \mathrm{m}^{2}\right)\end{array}$ & $\cdot 2$ 点の状態よりも劣る \\
\hline $\begin{array}{l}\text { (3) } \\
\text { 打重線 }\end{array}$ & & & & \\
\hline & $\begin{array}{l}\text { ·近接では打重ね格が缐認められる } \\
\text { もの, 約 } 10 \mathrm{~m} \text { 離れた遠方か } \\
\text { らは認められてい }\end{array}$ & $\begin{array}{l}\text { ·約 } 10 \mathrm{~m} \text { 耀れた遠方から，打重 } \\
\text { 線が認められる }\end{array}$ & $\begin{array}{l}\text { ・約 } 10 \mathrm{~m} \text { 離れた遠方から, 打重 } \\
\text { ね線がりきりと認められる }\end{array}$ & $\cdot 2$ 点の状態よりも劣る \\
\hline $\begin{array}{l}\text { (4) } \\
\text { 型枠継ぎ目の } \\
\text { Jロ漏れ }\end{array}$ & & & & \\
\hline & 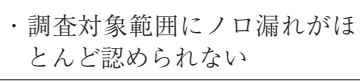 & 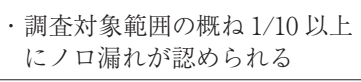 & $\begin{array}{l}\text { ·調查対象範囲の概ね } 1 / 3 \text { 以上 } \\
\text { にノ漏れか認められる }\end{array}$ & $\cdot 2$ 点の状態よりも劣る \\
\hline $\begin{array}{c}\text { (5) } \\
\text { 砂すじ }\end{array}$ & & & & \\
\hline & $\begin{array}{l}\text { ·調查対象範囲に砂すじがほと } \\
\text { んど怘められない }\end{array}$ & $\begin{array}{l}\text { ·調查対象範䧃の概ね } 1 / 10 \text { 以上 } \\
\text { に砂すじが認められる }\end{array}$ & $\begin{array}{l}\text { ·調查対象範囲の概ね } 1 / 3 \text { 以上 } \\
\text { に砂すじが認めらる }\end{array}$ & $\cdot 2$ 点の状態よりも劣る \\
\hline
\end{tabular}

図-1 一般構造物用の目視評価法の評価項目と評価基準

分である場合，はく離剤の塗布に問題がある場合や，脱型 時間や脱型までの養生温度に問題がある場合等がある。

(2)気泡は，特に傾斜のついたSLより下の側壁で発生 しやすい。

(3)水はしり・砂すじは一つの事象として扱うこととし た。SLより下の側壁やアーチ部の下部で，ブリーディ ングの除去が十分でない場合等に発生しやすい。

(4)色むら，打重ね線は，本来は別の事象であるが，卜 ンネル覆エコンクリートを観察すると, 多くの場合で打 重ね線の近傍で色むらが発生しており，別の項目にする
と実構造物での評価が困難になることを勘案して，一つ の評価項目にまとめることとした。色むら，打重ね線は， アーチ部の上部や天端部で発生しやすい。

なお， 既設の NATMトンネルの点検デー夕の分析に より，1992 年から 2007 年に完成した 12 のトンネルの 覆工コンクリートの施工目地から離れた箇所でのうき . はく離・はく落が 95 箇所あり，そのうちの 83 箇所が色 むらのある領域と関連していた9)。色むらがある箇所が うき・はく離・はく落に至るというわけでは決してない が，色むらを抑制する努力は，将来のうき・はく離・は 


\begin{tabular}{|c|c|c|c|c|c|}
\hline \multirow{2}{*}{ 評価項目 } & \multirow{2}{*}{ 不具合の写真 } & \multicolumn{4}{|c|}{ 評価基準 } \\
\hline & & 4 点 & 3 点 & 2 点 & 1 点 \\
\hline $\begin{array}{c}\text { 1) } \\
\text { はく離 }\end{array}$ & & 無し & $\begin{array}{l}50 \mathrm{~cm} \text { 四方程度の } \\
\text { 大きさで見られる }\end{array}$ & $\begin{array}{c}1 \mathrm{~m}^{2} \text { 程度の大きさで } \\
\text { 見られる }\end{array}$ & $\begin{array}{l}2 \text { 点の状態以上に } \\
\text { 広範囲に見られる }\end{array}$ \\
\hline $\begin{array}{c}\text { (2) } \\
\text { 気泡 } \\
(1.5 \mathrm{~m} \times 1.0 \mathrm{~m} \text { 範囲で調查 })\end{array}$ & & $\begin{array}{c}5 \mathrm{~mm} \text { 以下の気泡も } \\
\text { ほぼ無し }\end{array}$ & $\begin{array}{l}5 \mathrm{~mm} \text { 程度の気泡が } \\
10 \text { 箇程度見られる }\end{array}$ & $\begin{array}{l}10 \mathrm{~mm} \text { 以上が } 10 \text { 箇程 } \\
\text { 度または } 5 \mathrm{~mm} \text { 以下が } \\
20 \text { 箇程度見られる }\end{array}$ & $\begin{array}{c}10 \mathrm{~mm} \text { 以上が } 20 \text { 箇 } \\
\text { 程度見られる }\end{array}$ \\
\hline 水はしり·砂すじ & & 無し & $\begin{array}{c}\text { 一部に見られる } \\
\text { (全体の } 1 / 10 \text { 程度) }\end{array}$ & $\begin{array}{l}\text { やや多く見られる } \\
\text { (全体の } 1 / 3 \text { 程度) }\end{array}$ & $\begin{array}{l}2 \text { 点の状態以上に } \\
\text { 広範囲に見られる }\end{array}$ \\
\hline 色むら, 打重ね線 & & ほぼ無し & $\begin{array}{l}\text { 一部に見られる } \\
\text { (全体の } 1 / 10 \text { 程度) }\end{array}$ & $\begin{array}{c}\text { 全体の半分程度に } \\
\text { みられる }\end{array}$ & $\begin{array}{l}2 \text { 点の状態以上に } \\
\text { 広範囲に見られる }\end{array}$ \\
\hline$\stackrel{(5)}{\text { 施工目地不良 }}$ & & 無し & $\begin{array}{l}\text { 一部に見られる } \\
\quad(1 / 10 \text { 程度 })\end{array}$ & $\begin{array}{c}\text { 多く見られる } \\
\text { (1/3 程度) }\end{array}$ & $\begin{array}{l}\text { 側壁全てに見られる } \\
\text { (天端に見られたら }\end{array}$ \\
\hline $\begin{array}{c}\text { 6 } \\
\text { 検查窓杵段差 }\end{array}$ & & 無し & 1 箇所程度見られる & 2〜3 箇所見られる & $\begin{array}{c}3 \text { 箇所を越える個所 } \\
\text { に発生 }\end{array}$ \\
\hline
\end{tabular}

図-2トンネル覆エコンクリート用の目視評価法の評価項目と評価基準

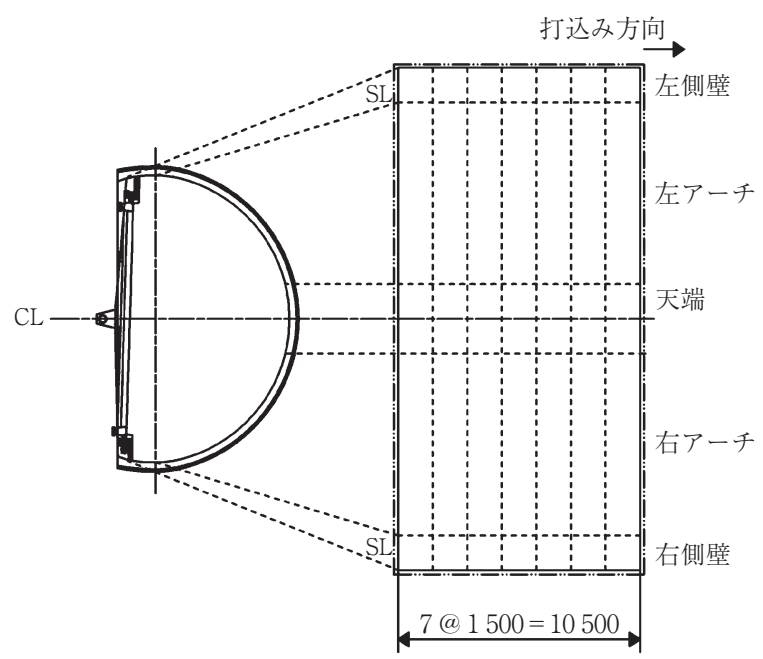

図-3＼cjkstart覆エコンクリートでの目視評価の実施位置

く落のリスクを低減することにつながると考えられる。

(5)施工目地不良は, 施工目地部の目地材の固定が十分 でない場合に，本来の設置場所から目地材が動くことに より生じる。
(6)検査空枠段差は, 検査空の固定が十分でない場合や, セントル本体と検査空にすき間がある場合等に生じるた め，適切な事前準備により防ぐことができ，東北地方整 備局の試行工事ではほとんどの現場で 4 点であった。

以上の 6 項目を脱型後に評価し，適切な事前準備や材 料や打达み方法の改善にフィードバックすることで, PDCAによる品質向上が可能となる。特に, トンネル 覆工コンクリートの場合は, 同じ形状の部材を, 同じメ ンバーで，短い日間隔で打込みを重ね，環境条件の影響 を受けにくいこともあるため，比較的 PDCA が機能し やすい部材であると考えている。

\section{3 目視評価法の特徵}

目視評価法を実構造物の品質確保の試行工事に導入し た結果，以下に示すような目視評価法の特徵が把握でき た。目視評価法の効果の具体的な説明は，実構造物での 事例と合わせて，3 章で詳述する。

（1）型枠脱型後のコンクリート表層の状態について, 項目に分け，評価基準を与えたことで，これまで漫然と 眺めていた出来ばえが，より明確に見えるようになった。 
（2）究極の非破壊試験である。特別な器具は不要で，基 本的に離れた箇所からも評価は可能なので，特別な足場も 不要である。脱型直後から実施可能である。評価に必要 な時間も短く，1エリアの評価に 1 ～ 2 分で十分である。

（3）評価エリア全体の品質を評価できる。表層品質の 評価を, リバウンドハンマー, 表層透気試験, 表面吸水 試験等で行う場合は，基本的に局所的な点での評価とな り，全体を評価することは不可能である。この目視評価 法の場合は，エリア全体を見たうえで，改善が必要と評 価者が思うときにはそれを反映した数值を付けるため, 簡単な手法ではあるが，全体を評価していることになる。 仮に不具合が一部分に集中している場合であっても，そ の状態を次にどう改善したいのかがポイントであって， それを反映した評価結果にすればよいのである。

（4）多くの人が同時に実施できる。一般的な試験は, 技術を持つ人間が少人数で行う場合がほとんどである。 この目視評価法は，発注者，施工者，作業員等が容易に 行うことができる。最大の特長は，仮に評価の結果が低 い場合でも，次への改善策を提案できる場合が多い，と いうことである。コンクリートの表層に現れた不具合に は理由があり，技術，経験を持つものであれば，理由の 推察も付くし，改善方法を提案することができる。この 特長が適切に活用されることにより，コンクリート構造 物の建設に携わる関係者の協働的な対話につながること を筆者らは期待している。

3. 一般構造物の品質確保における目視評価法の 効果

ここでは，橋脚，橋台，隶渠等の一般的な構造物にお いて，施工状況把握チェックシートと目視評価法を活用 した品質確保の試行工事等で見られた目視評価法の効果 や施工者の工夫等について述べる。なお， 2016 年 7 月 現在で，東北地方整備局の管内において，特記仕様書で 両手法を活用した品質確保の試行が明記された橋梁下部 工は 43 件である。

東北地方整備局の「コンクリート構造物の品質確保の手 引き (案) (橋脚, 橋台, 函渠, 擁壁編)」と「コンクリー ト構造物の品質確保の手引き（案）（トンネル覆工コンク リート編)」においては, 脱型後の追加養生を行い, その 効果を表層透気試験 ${ }^{11)}$ および表面吸水試験 $(\mathrm{SWAT})^{12)}$ 等で評価することを推奨している。一般構造物およびトン ネルにおいては，表層透気試験（トレント法）から得られ る表層透気係数で $1.0 \times 10^{-16} \mathrm{~m}^{2}$ 以下, SWAT で得られる 10 分時点での表面吸水速度 $\left(p_{600}\right)$ で $0.50 \mathrm{ml} / \mathrm{m}^{2} / \mathrm{s}$ 以下 を目指すことが手引きにおいて示されている。以下に示 す実構造物の品質の評価にこれらの手法も活用した。

\section{1 唐丹第二高架橋, P 1 橋脚での PDCA}

この現場は特記仕様書で規定された試行工事の対象で はない。しかし，2014 年 6 月 4 日に南三陸国道事務所
で開催された品質確保の講習会（第一著者，第四著者が 講師）での情報を参考に，施工者が監督職員との協働に より品質確保についての様々な工夫を行った工事である。

$7.5 \mathrm{~m} \times 4.5 \mathrm{~m}$ の中実断面で高さ $25 \mathrm{~m}$ の橋脚である。 セメントは高炉 $\mathrm{B}$ 種，呼び強度は $27 \mathrm{~N} / \mathrm{mm}^{2}$ ，W/C は $53.5 \%$ ，スランプは $8 \mathrm{~cm}, \mathrm{G}_{\max }$ は $20 \mathrm{~mm}$ であり，ひび 割れ抑制のために澎張材が $20 \mathrm{~kg} / \mathrm{m}^{3}$ 使用されている。 5 リフトに分割して施工されており，第1リフト（2014 年 8 月 5 日打込み), 第 4 リフト (10月 3 日打达み), 第 5 リフト（10月 16 日打込み）で目視評価等の調査を 行った。

施工段階で以下の工夫が行われている。

・ポンプ車の筒先に材料分離低減用のホースが取り付け られ，型枠内へのコンクリートの落下がコントロール されている。

・透明型枠（明かり取り用樹脂製型板）が各リフトの一 番下層の型枠に，千鳥配置で用いられた。

・フレッシュコンクリート用の改質剤（人工ゼオライ ト・アクリル酸・界面活性剂・他）が現場でアジテー 夕車に後添加された。

・型枠脱型後に高発泡ポリエチレンシートで養生した。 この現場では，目視評価法を活用して，橋脚を打ち上 がっていくにつれての PDCA が実践されていた。図-4 に示すように，目視評価においても PDCAの効果が見 られ，第 5 リフでは，わずかな気泡を除いてすべて 4 点の出来ばえであった。また，図-5に示すように，吸 水抵抗性も極女て高く，打重ね線上のみならず，打継ぎ

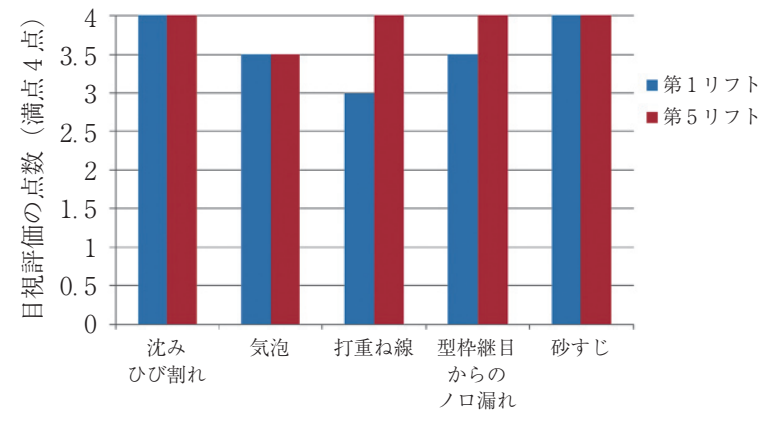

図-4＼cjkstart目視評価の結果（唐丹第二高架橋 P 1）

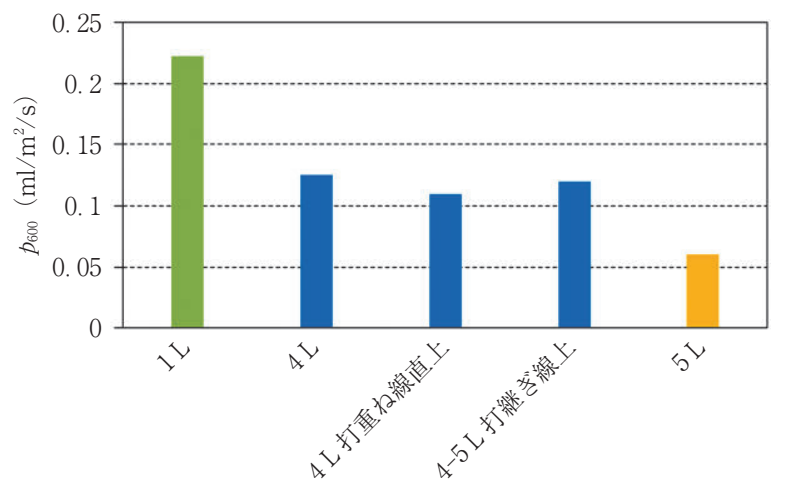

図-5ＳWAT の計測結果（唐丹第二高架橋 P 1） 
の直上でも高い吸水抵抗性を示した。

\section{2 小佐野高架橋, A 2 橋台における施工の工夫}

この現場は南三陸国道事務所が発注した工事であり， 品質確保の試行工事の対象である。この現場では，橋台の たて壁および胸壁の横の長さが $22.5 \mathrm{~m}$ 程度あったため, 山口県のひび割れ抑制対策 ${ }^{13)}$ を参考に，ひび割れ幅抑制 のため追加鉄筋を配置し，ひび割れ抑制にも取り組んだ。

橋台のたて壁と胸壁のコンクリートには，高炉セメン トB種が用いられ，呼び強度は $24 \mathrm{~N} / \mathrm{mm}^{2}$ ，スランプは $8 \mathrm{~cm}, \mathrm{G}_{\max }$ は $25 \mathrm{~mm}$ である。2 分割で施工されたたて壁 の第 1 リフト (2015 年 12 月 17 日打込み), 第 2 リフト (2015 年 12 月 29 日打込み), および胸壁（2016 年 1 月 17 日打込み）はすべて，2月1日に脱型され，4月 17 日まで写真-2に示すシート養生による追加養生を行っ た。これらについて，2016 年 4 月 26 日に表層品質の調 査を行った。シート養生の表層品質向上の効果を調べる ため, 各リフトに $1 \mathrm{~m} \times 1 \mathrm{~m}$ のシート養生を行わない領 域を設け，脱型後は外気にさらされる状況とした。

施工段階で以下の工夫が行われている。

写真-1 に示すように，型枠継ぎ目からのノロ漏れを 防止するために，鉛直および水平の型枠継ぎ目にスポン ジ状の隙間テープを配置した。

写真-2 は, 脱型後にビニールシートにより追加養生 を行っている状況である。

上記以外にも，一層の打込み高さの管理のために，組

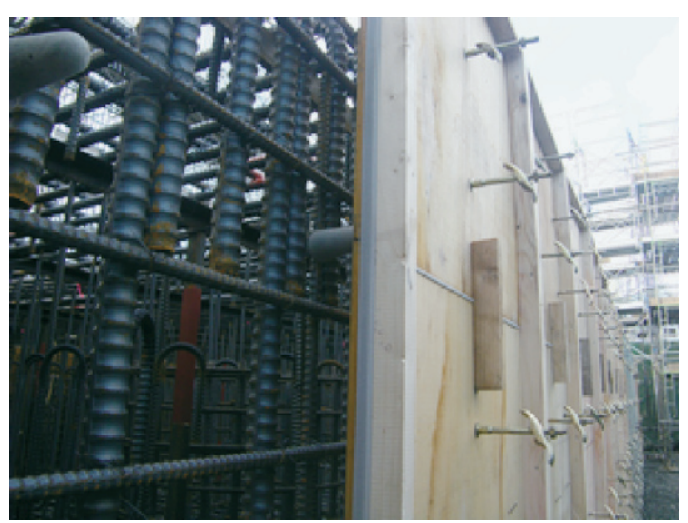

写真-1 ノロ漏れ防止のための隙間テープ

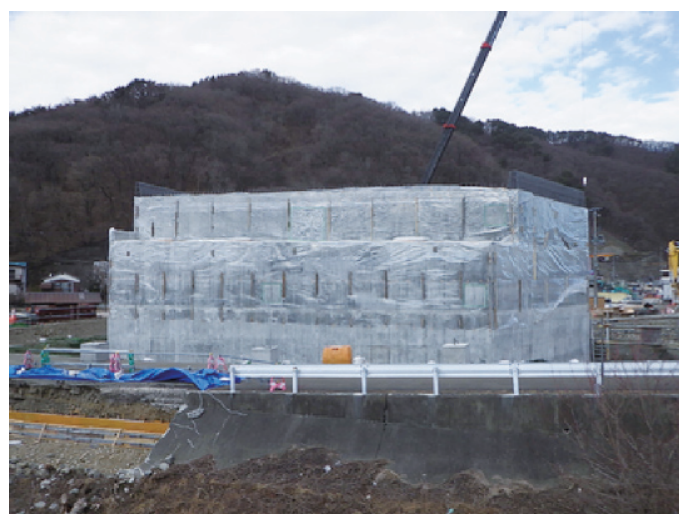

写真-2 シートによる追加養生
立て用の鋼材に $50 \mathrm{~cm}$ ごとのマーキングをしたり，ポン プの筒先やバイブレータの挿入口をマーキングしたり， 表面気泡の低減のためのスページングや丁寧な型枠たた き，ブリーディング水のこまめな排除，打込み作業の役 割表を現場に掲示して役割の明確化を行うなどの工夫が なされた。

図-6に目視評価の結果を示した。この構造物では, たて壁と胸壁を同時に脱型しシシート養生を開始したた め，たて壁の目視評価の結果は胸壁の施工に直接フィー ドバックはされていない。また，たて壁は２リフト分を まとめて評価した結果である。たて壁の打込み中に一カ 所でセパレー夕が破断したことに起因するノロ漏れによ り 3.5 点の評価となった。また，気泡を低減するための 努力は行ったものの，部材側面の上部に気泡が残存する 結果となった。満点の 4 点ではないし，3.5 点を付けるに はまだできる努力がある気がする，という議論が監督員 と施工者の間で行われ，A 1 橋台の施工への PDCA に つなげる意味を込めて 3 点を付けた，とのことである。

図-7にSWAT の計測結果を示した。シート養生を行っ た場所は，行わない箇所に比べて含水率がやや高い傾向 にあり，吸水抵抗性も顕著に高かった。気泡が目立った たて壁 2 リフの上部や，たて壁の打継目においても非 常に高い吸水抵抗性を示した。

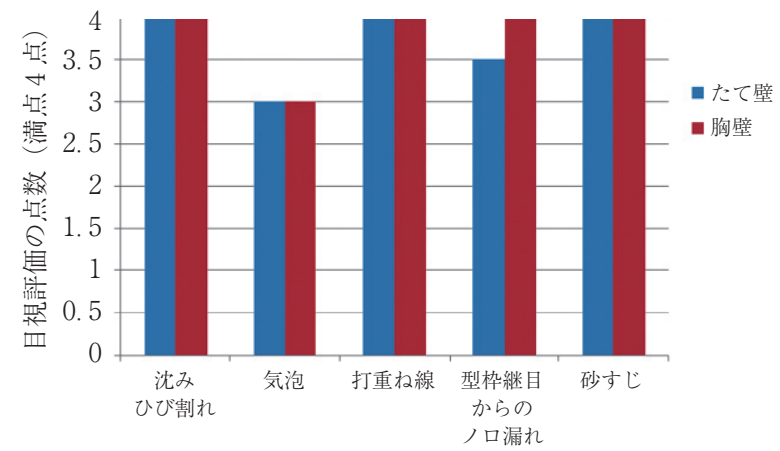

図-6＼cjkstart目視評価の結果（小佐野高架橋 A 2)

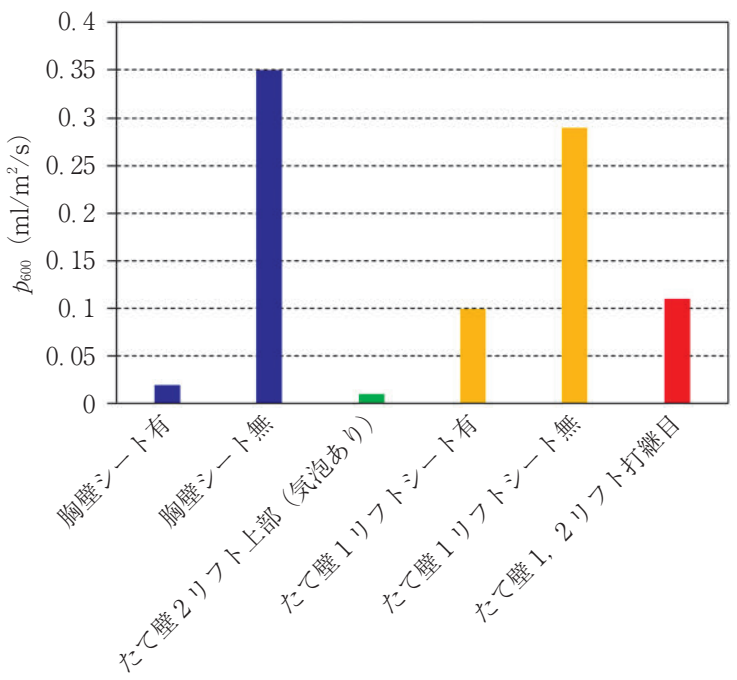

図-7ＳWAT の計測結果（小佐野高架橋 A 2) 
3.3 新小本大橋の下部工, 透水型枠等を用いた工夫 ${ }^{14}$

この現場は，東北地方整備局が発注した工事であり， 品質確保の試行工事の対象である。下部工の正式な試行 工事としては，最初に打込みが行われた現場であった。 八戸工業大学の阿波稔教授らの開発した寒中コンクリー 卜用の施工状況把握チェックシート ${ }^{8)}$ も活用された。

下部工に使用するコンクリートのブリーディングが多 いことが事前の調査で分かっていたこともあり，表層品 質を向上させるため，透水性型枠が用いられた。普通ポ ルトランドセメントを使用し，呼び強度は $24 \mathrm{~N} / \mathrm{mm}^{2}$, スランプは $12 \mathrm{~cm}, \mathrm{G}_{\max }$ は $25 \mathrm{~mm}$ である。橋脚は河川 内に立てられるため小判型をしている。

冬季施工中は特にブリーディング水の排除をこまめに 行い，脱型後はシート養生を行った。

写真-3 に新小本大橋の P 2 を示す。すべての橋台，橋 脚の表面が黒っぽい仕上がりとなった。透水性型枠を用 いたこともあり，沈みひび割れ，表面気泡はほとんど観 察されなかった。図-8にこの現場で苦労した打重ね線 と砂すじに関する目視評価の結果を示した。初期の冬季 施工時に，ブリーディング水の排除の努力を行ったもの の，打重ね線が認められ，特に橋脚の曲線部に砂すじが 局所的に発生した。橋脚の曲線部の型枠の固定の強化や, 型枠付近でブリーディング水を排除しないことや，バイ ブレータの下層への適切な挿入の徹底などの改善を重ね, 後半では 3.5 点以上の良好な出来ばえを達成した。

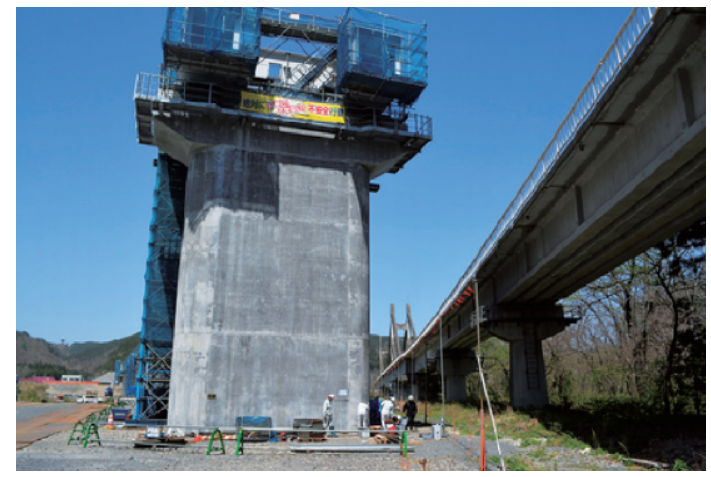

写真-3 新小本大橋 P 2

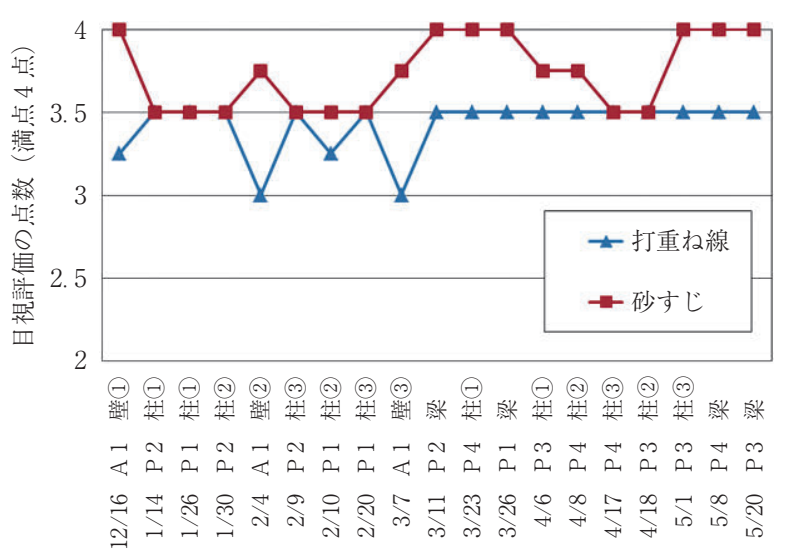

図-8＼cjkstart目視評価の結果（新小本大橋）
SWAT の計測は 2016 年 4 月 24 日に行った。図-9に P 2 で計測したSWATの結果を示す。透水性型枠を使 用した面では極めて高い吸水抵抗性を示した。型枠継目 部でも計測し，数值では $0.24 \mathrm{ml} / \mathrm{m}^{2} / \mathrm{s}$ と高い吸水抵抗 性を示したが，型枠継目のわずかなノロ漏れに沿って水 が遡上する様子が認められた。

\section{4 大畑団地本線 Box における品質の評価}

この現場は特記仕様書で規定された試行工事の対象で はないが，前述の 2014 年 6 月 4 日に南三陸国道事務所 での講習会を契機に，施工状況把握チェックシートを活 用して施工された現場である。

写真-4 に示すような, ボックスカルバート構造物の側 壁が対象である。高さ $8.7 \mathrm{~m}$, 幅 $18.2 \mathrm{~m}$, 厚さ $1.6 \mathrm{~m}$ の 側壁を 2014 年 7 月 2 日に打継ぎ無しで打ち上げている。 セメントは高炉 B 種，呼び強度は $27 \mathrm{~N} / \mathrm{mm}^{2} ， \mathrm{~W} / \mathrm{C}$ は $49 \%$ ，スランプは $8 \mathrm{~cm}, \mathrm{G}_{\max }$ は $25 \mathrm{~mm}$ ，単位水量は $147 \mathrm{~kg} / \mathrm{m}^{3}$ であった。この構造物の施工では，施工状況 把握チェックシートの活用がなされており，施工の基本 事項の遵守を心掛けたにもかかわらず，写真-4に示す ように打重ね線がほぼ平行にくっきりと見られた。一層 の厚さは丁寧に管理されており，下層にバイブレータも 適切に挿入されたが，夏季の打込みということもあり， 打重ね線が残る結果となった。

打重ね線の直上と，打重ね線以外での品質の差異に着 目して，目視評価，SWAT，表層透気試験を実施した。

図-10に，側壁の下部で行った目視評価の結果を示し た。写真-4でも示した打重ね線により，評価值が低く なっている。その他の項目はすべて 3 点以上であった。

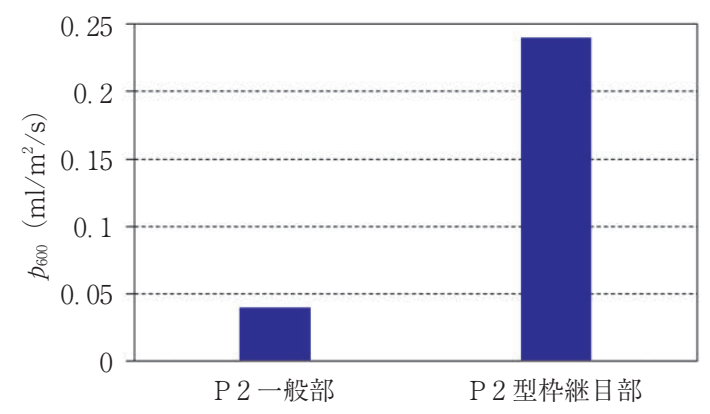

図-9ＳWAT の計測結果（新小本大橋 P 2)

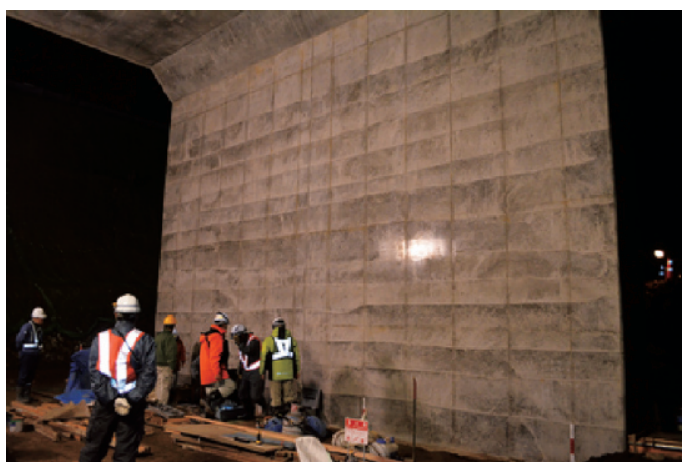

写真-4 大畑団地本線 Box の側壁 


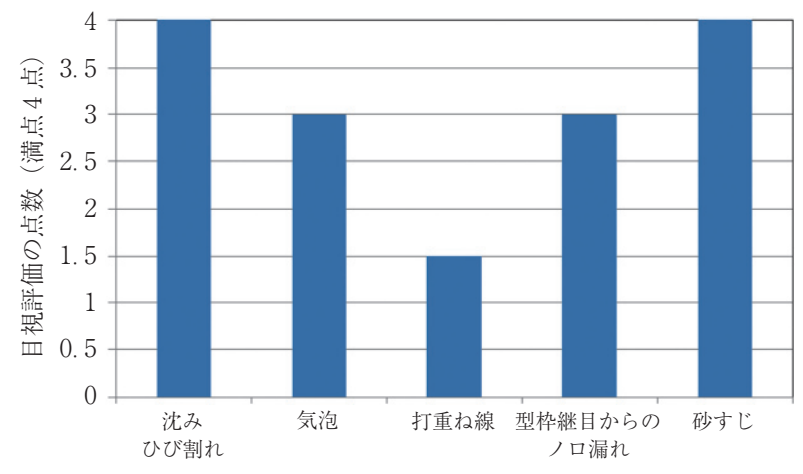

図-10 目視評価の結果（大畑団地本線 Box）

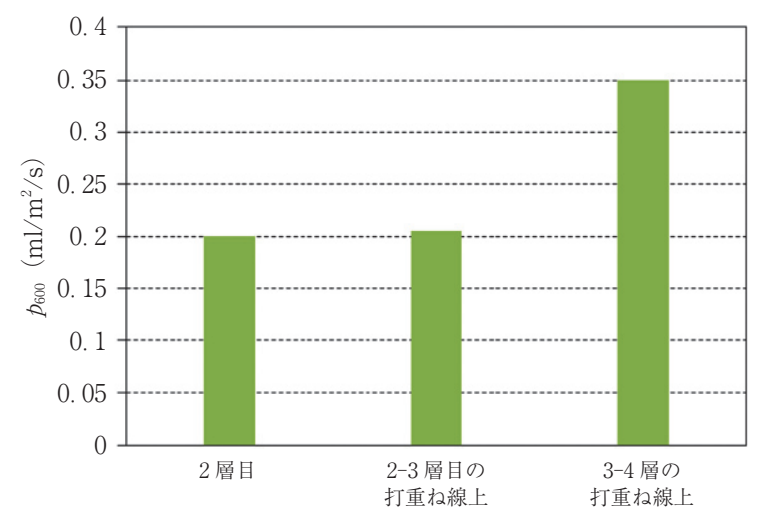

図-11 SWAT の結果（大畑団地本線 Box）

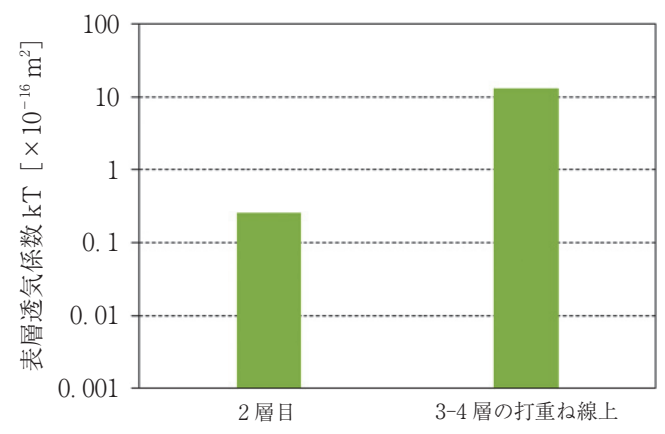

図-12 表層透気試験の結果（大畑団地本線 Box）

図-11に, SWAT の結果を示した。2 点の計測結果の平 均であり，それぞれの計測点で 2 点間のばらつきも小さ かった。視覚的には明暸な打重ね線の直上で計測した場 合でも，吸水抵抗性が顕著に劣ることはなかった。吸水 抵抗性の観点からは各層は一体化していると判断できる。

図-12に，表層透気試験の計測結果を示した。打重ね 線の上では, 約 2 桁大きい透気係数が計測された。この 構造物では他の打重ね線でも表層透気試験を行ったが, 計測不能とされる箇所もあり，打重ね線上では著しく低 い透気抵抗性を示した。

毛管張力による吸水が支配的な SWAT で十分な吸水 抵抗性を示していることから，筆者らはこの構造物の打 重ね線は耐久性上問題になるものではないと考えている。

凝結の早い夏場の打込みでは，この事例のように，耐 久性には問題ないであろうが打重ねが明瞭に発生する場 合もある。この理由としては，夏場は型枠面が比較的熱
くなり、コンクリートのごく表面の打重ね部で凝結が早 くなること等の影響を受けるものと推察される。この構 造物の表層品質の調査時にも，さらに出来ばえを良くす るための施工の工夫についての議論が施工者を含む参加 者の間でなされた。

4. トンネル覆工コンクリートの品質確保におけ る目視評価法の効果

ここでは，トンネル覆エコンクリートに扔いて，施工 状況把握チェックシートと目視評価法を活用した品質確 保の試行工事等で見られた目視評価法の効果や施工者の 工夫等について述べる。なお，2016 年 7 月現在で，東 北地方整備局の管内において, 特記仕様書で両手法を活 用した品質確保の試行が明記されたトンネル工事は 46 件である。

\section{1 田老第六トンネルでの PDCA}

この工事は, 東日本大震災後に復興道路では初めて貫 通したトンネルであり，トンネル覆工コンクリートの品 質確保に関して施工者と第一著者が協働する形で試行を 行った。図-2で示した覆エコンクリート用の目視評価 法をこの工事で開発し，品質確保に活用した ${ }^{10}$ 。

このトンネルは，3\%の勾配があり，1ブロック当り， ラップ側とつま側で高低差が約 $30 \mathrm{~cm}$ 生じるため, 既設 コンクリートと接するラップ側覆工コンクリートの天端付 近に空洞を生じさせない施工管理が必要であった。坑口 付近のブロック（1〜 4 BL，28 BL）を除いた一般部（5〜 $27 \mathrm{BL} ）$ の覆工コンクリートには, 呼び強度 $18 \mathrm{~N} / \mathrm{mm}^{2}$ のコンクリート（高炉セメント，スランプ $15 \mathrm{~cm}$ ）が使 用された。

打込みに扔いては，側壁の打込みと同様な締固めをよ り高い位置まで行うための肩部吹上げ口の増設，圧力七 ンサで管理されたコンクリート加圧充填と引抜きバイブ レータによる締固め, 覆工背面の凹凸に起因する残留工 アおよびブリーディング水の強制排出を目的とした吸引 チューブの設置などを行った。

この工事では，坑口のコンクリートの耐凍害抵抗性を 向上する目的で，発注者指示による追加養生として，両 坑口から 2 ブロック分の $21.0 \mathrm{~m}(10.5 \mathrm{~m} \times 2$ ブロック $)$ 区間の型枠を 1 週間存置することとした。また，上記以 外の区間に対してバルーン養生を行うことを原則とし た。コンクリート打込み直後から脱型までセントル全体 を覆うセントルバルーンを設置し，セントル移動後は後 方 3 ブロック分をコンクリート用バルーンで養生した。 バルーンによる養生日数は, 脱型後 1 週間以上とするこ とを原則に工程計画を立てた。

目視評価の結果を図-13 に示す。図-13には, トンネ ル覆工コンクリートの部位によって評価点が低くなりや すい色むら・打重斌線と気泡の評価結果を示した。天 端・肩部に発生しやすい色むら・打重ね線は，この工事 
において前述した天端・肩部の打込み工法が確立できた 4 ブロック以降で概ね高得点であった。一方，側壁部に 発生しやすい気泡については, PDCA サイクルで試行 錯誤を繰り返した結果，ようやく20ブロック以降で高 得点で安定する結果となった。しかし，この工事では $18 \mathrm{~N} / \mathrm{mm}^{2}$ という低強度の配合（標準仕様）を用いたた め, 全体的にSL下部の気泡の抜けが悪い状況であった。

この現場においては，第 5 ブロックにおいてほぼ満足 できる出来ばえが達成できたが，その後，作業チームの 慢心やコンクリートの品質変動等の影響もあり, 評価点 が一時低下した。しかし，16ブロックのコンクリート 打込み前に実施した全作業員を含む現場検討会の影響が 大きく，それ以降は高得点での安定した推移が見られた。

図-14には, SWATの結果を示した。平均值と最大・ 最小值を示している。測定箇所は, トンネル断面の SL 付 近で, 縦断方向は各ブロック $10.5 \mathrm{~m}$ の中央付近とした。 材齢は 4 週以上である。型枠を 1 週間存置したブロックは, 工事起点側坑口から 2 ブロックである（第 1 ブロック：呼 び強度 $30 \mathrm{~N} / \mathrm{mm}^{2}$ ，第 2 ブロック呼び強度 $\left.24 \mathrm{~N} / \mathrm{mm}^{2}\right) 。$ 無養生の第 3 ブロック（呼び強度 $30 \mathrm{~N} / \mathrm{mm}^{2}$ ) は, 型枠 残置 1 週間を実施した隣のブロックである。バルーン養 生 (貫通前) の $p_{600}$ は, トンネル貫通前に覆工コンクリー ト打込みを行ったブロックで測定したものであり,ここ

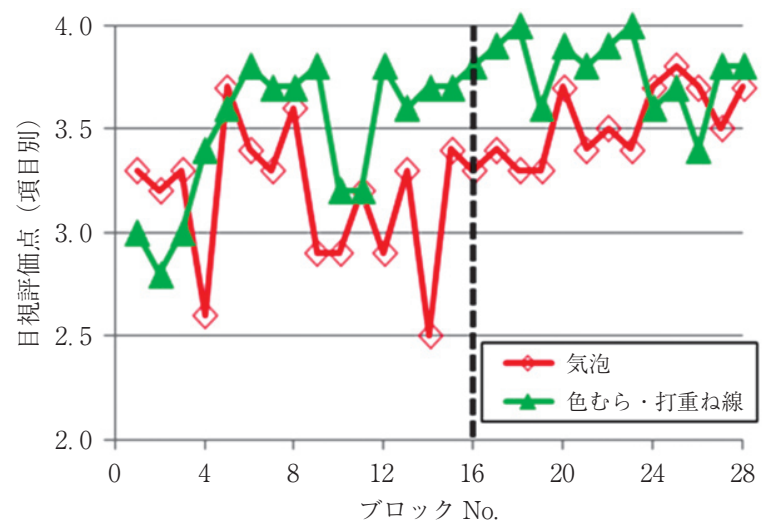

図-13 目視評価の結果（田老第六トンネル，5部位平均）

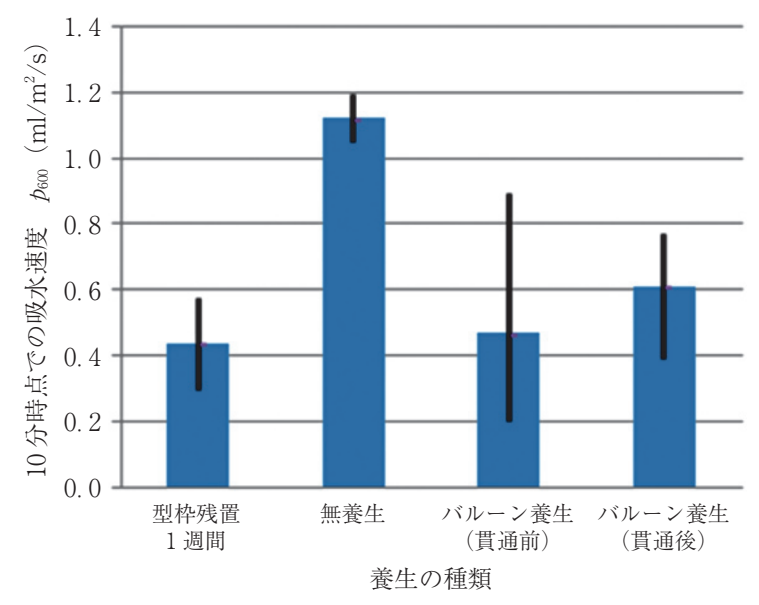

図-14 SWAT の結果（田老第六トンネル）
では 15 ブロック分の平均值である。同様に, バルーン 養生（貫通後）は 4 ブロック分の平均值である。

図-14によると, 型枠存置 1 週間およびバルーン養生 は，無養生（標準的な施工条件）に比べ，いずれも $p_{600}$ が小さくなっており, 吸水抵抗性が養生の効果で向上し たことがわかる。とくにバルーン養生（貫通前）は低強 度配合でありながら, 配合強度が高くかつ型枠存置 1 週 間としたブロックと同等の表層品質が達成できているこ とが明らかとなった。

4.2 鵜住居第二トンネルでの施工目地部に関する工夫 この現場は, 東北地方整備局が発注した工事であり, 品質確保の試行工事の対象である。この現場では, 基本 的に呼び強度 $24 \mathrm{~N} / \mathrm{mm}^{2}$ で W/C が $51 \%$ ， セメントは高 炉 $\mathrm{B}$ 種のコンクリートを用いた。施工の基本事項の遵 守に加えて, 施工目地部に発生するうき・はく離・はく 落を低減するための工夫を行った ${ }^{15)}$ 。

図-15に，筆者らの推察する施工目地付近での不具合 の発生メカニズムを示す。後打ちコンクリートの打込み 後, コンクリートの温度や収縮による体積変化により, 後打ちコンクリートと先打ちコンクリートは離れる方向 に変形する。図-16は，復興道路の実際のトンネルの二 つの施工目地をまたぐ形で設置した標点間 $250 \mathrm{~mm}$ のコ ンタクトゲージで計測した目地の開きである。二つの目 地ともに同様の挙動を示しており，打込み後20日程度 で 2〜3 mm 程度の開きを示した。このときに，既設コ ンクリートと後打ちの新設コンクリートの間に付着が存 在する場合, 弱点部に沿ってひび割れが発生し，うきに つながる可能性を考えている。

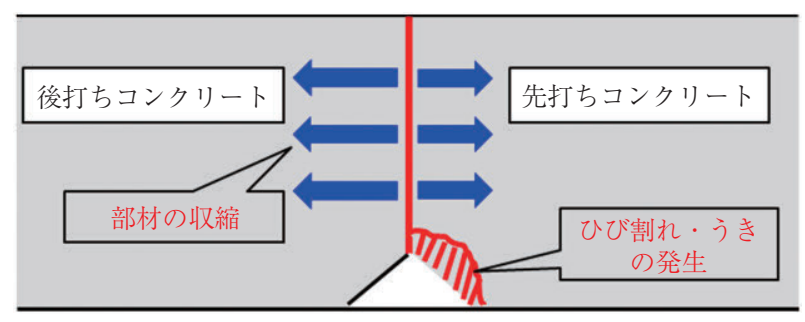

図-15＼cjkstart施工目地部に不具合が発生する機構の推察

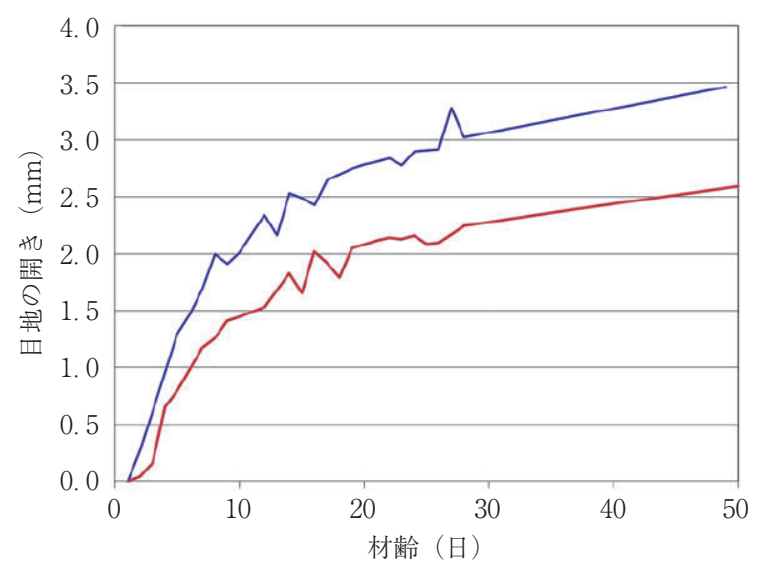

図-16 実構造物で計測した打込み後の目地の開き 


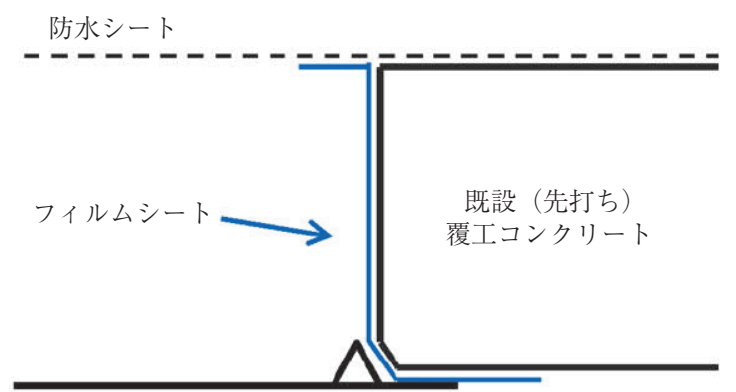

図-17 ビニールシートによる対策の概念図

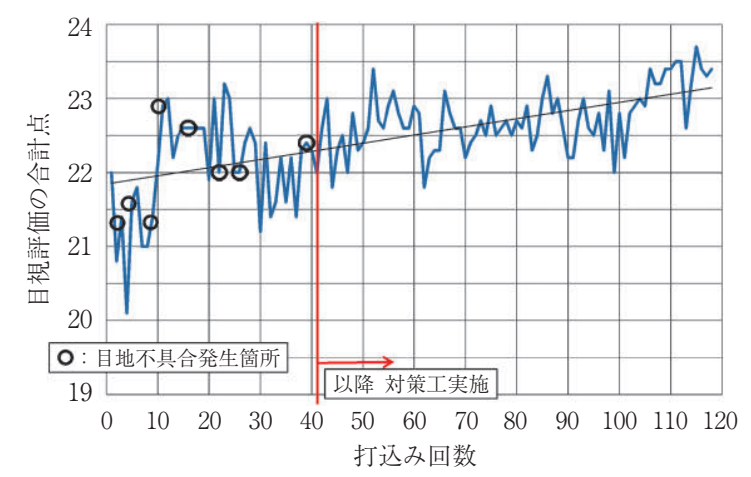

図-18 目視評価の結果（24 点満点）と施工目地部の対策の効果

図-15の概念図においては，既設コンクリートの側に 不具合が生じる状況を描いている。強度がより発現して いるはずの先打ちの既設ブロック側に不具合が生じる目 地部が, 現場においては少なくない。その理由として, 筆者らは先打ち部のつま部に, コンクリートの品質が低い 部分が生じる場合があることによる可能性を考えている。

この施工目地部のひび割れ・うきを防止するために, 目地部にビニールシートを設置し, 既設のコンクリート との縁を完全に切り，拘束を無くす対策が開発された ${ }^{15)}$ 。 この対策の概念図を図-17 に示す。

使用したビニールシートは厚さ $0.2 \mathrm{~mm}$ の薄手のフィ ルムシートであり, 安価で, 特殊な化学組成等も必要と しないので入手も容易である。セントル脱型後, 既設の 覆エコンクリートのつま部に貼り付ける。このとき, 新 設のコンクリートが既設のコンクリートに直接触れるこ との無いよう，つま部を完全に覆うように取り付ける必 要がある。ビニールシートの端部は目地に沿わせてセン トルの外部一出し, 新設のコンクリートに巻き込まれな いように配慮した。

目地部の変状の有無を確認するために目視調査を行っ た。図-18 のグラフには，施工管理の推移を示すための 目視評価の合計点（6 項目で 24 点満点）と変状が確認 されたスパンに○印を記載しており，ビニールシートに よる対策工の開始時期も示した。ビニールシートによる 対策工の実施前は，施工の基本事項の遵守の努力をして も目地部の不具合は根絶はできていない。しかし，ビニー ルシートによる対策を開始して以降は, 目地部に変状は 発生していない。なお，ここでは説明しやすくするため
合計点で示したが，評価の際は個々の項目で評価し，合 計してはならない。

一般的なコンクリートを用いて覆エコンクリートの施 工目地部の不具合を根絶するためには, 施工の基本事項 の遵守のみでは不十分であり，本稿に示すような対策を 別途施す必要がある。

\section{5.おわりに}

コンクリート構造物の型枠脱型後に, 表面の出来ばえ を項目ごとに定量評価する目視評価法の特徵と, 品質確 保の試行工事等に扔ける目視評価法の効果について述心゙ た。出来ばえを適切に評価することは，施工者の工夫を 促すことを，実際の工事の事例で紹介した。また，出来 ばえを定量評価することが，本稿でも紹介した透水型枠 の使用によるブリーディングの影響の低減や，既報》で も紹介したブリーディング低隇技術の開発や活用等を活 性化する効果も認められている。

コンクリート構造物の耐久性に大きな影響を及ぼす表 層品質が適切に評価されることを通じて, 耐久的なコン クリート構造物が構築されることに本稿が一助となれば 幸いである。

\section{参 考 文 献}

1）土木学会：2012 年制定コンクリート標準示方書 [設計編], 2012

2）日本コンクリート工学会：コンクリート診断技術’15 [基礎編], 2015

3）廣井 勇：築港前編, 訂正第五版, p.168, 1929

4）吉田徳次郎：第 3 次改著 鉄筋コンクリート設計方法, 養賢堂, 1958

5）坂田 昇・渡邊賢三・細田 暁：コンクリート構造物の品質向上 と表層品質評価手法, コンクリート工学, Vol.50, No.7, pp.601〜 606, 2012

6）細田 暁：目視評価法を活用したコンクリート構造物の品質向上 マネジメント，建設物価，1143 号，pp.10～15, 2014. 2

7）坂田 昇・渡邊賢三・細田 暁：目視評価に基づくコンクリート 構造物の表層品質評価手法の実績と調査結果を反映した表層品質向 上技術，コンクリート工学，Vol.52，No.11，pp.999〜1006, 2014

8）川邊清伸・阿波 稔·須藤昌二・大森祐一：寒中コンクリート用 施工状況把握チェックシートを活用したコンクリート構造物の品 質確保の取組, コンクリート工学年次論文集, Vol.37, No.1, pp.1285 1290, 2015

9）岩間慧大・細田 暁：NATM トンネル覆工コンクリートの変状に 関する点検データの分析, コンクリート工学年次論文集, Vol.38, No.2, pp.1501 1505, 2016

10）伊藤忠彦·細田 暁・林 和彦 - 西尾 隆 -八巻大介：覆工コン クリート品質向上の取り組みと表層品質の評価, トンネル工学報 告集, 24 巻, I-4 号, pp.1 9, 2014. 12

11) R. J. Torrent : A two-chamber vacuum cell for measuring the coefficient of permeability to air of the concrete on site, Materials and Structures, Vol.25, pp.358-365, 1992

12）林 和彦・細田 暁：表面吸水試験によるコンクリート構造物の 表層品質の評価方法に関する基礎的研究, 土木学会論文集 $\mathrm{E} 2$, Vol.69, No.1, pp.82 97, 2013

13）二宮 純・森岡弘道・細田 暁・田村隆弘：山口県の実構造物の データを活用したひび割れ抑制設計, コンクリート工学年次論文 集, Vol.37, No.1, pp.1153 1158, 2015

14）高橋 雅・佐伯岳洋・小穴信太郎・阿波 稔：橋梁下部工におけ るコンクリート構造物品質確保への取組み, コンクリート工学年 次論文集, Vol.38, No.1, pp.1605 1610, 2016

15）宮田和実・目崎浩二・河内正道・細田 暁：NATM トンネル覆工 コンクリートの施工目地近傍の変状の抑制対策と効果, コンクリー 卜工学年次論文集, Vol.38, No.1, pp.1623〜 1628, 2016 